\title{
Peptides of amaranth were targeted as containing sequences with potential anti-inflammatory properties
}

\author{
Julian Moronta ${ }^{a}$, Paola L. Smaldini ${ }^{b}$, Guillermo H. Docena ${ }^{b}$, \\ María Cristina Añón ${ }^{a, *}$ \\ a Centro de Investigación y Desarrollo en Tecnología de Alimentos (CIDCA), CONICET-CCT La Plata y \\ Universidad Nacional de La Plata, La Plata, Argentina \\ ${ }^{\mathrm{b}}$ Instituto de Estudios Inmunológicos y Fisiopatológicos-IIFP, Facultad de Ciencias Exactas, Universidad \\ Nacional de La Plata y Consejo Nacional de Investigaciones Científicas y Técnicas, La Plata, Argentina
}

\section{A R T I C L E I N F O}

Article history:

Received 29 July 2015

Received in revised form 8

December 2015

Accepted 9 December 2015

Available online

Keywords:

Amaranth peptides

Immunomodulatory activity

Anti-inflammatory

Intestinal epithelial cells

CCL20

\begin{abstract}
A B S T R A C T
The immunomodulatory effect of amaranth peptides on epithelial cells activated through the NF-kB signalling pathway was examined. Results showed that extensive protein hydrolysis from amaranth (23 and 30\% degree of hydrolysis) reduced the emission of light in bacterial flagellin-activated Caco-2 CCL20: luc cells (Caco-2 cells transfected with a luciferase reporter under the control of the CCL20 promoter) compared with the non-hydrolysed protein. Purification of the most active peptide fractions by HPLC chromatography and sequencing showed that the peptide SSEDIKE possessed a modulatory capacity on activated cells to suppress the expression of mRNA coding for CCL20. This peptide was non-toxic for cells. These findings indicated that the peptide SSEDIKE derived from proteins of amaranth attenuated the activation of human intestinal epithelial cell, and hence amaranth proteins could be included in functional foods as a source of bioactive peptides with health promoting properties.
\end{abstract}

(c) 2015 Elsevier Ltd. All rights reserved.

\section{Introduction}

Consumers are becoming more demanding of high-quality foods, regarding their nutritional, organoleptic and health properties. There is a compelling evidence linking the rising incidence of chronic diseases (typical of modern and westernised societies) with the intake of certain foods (Bach, 2005; Chatterton, Ninh Nguyen, Brandt Bering, \& Torp Sangild, 2013; Feillet \& Bach, 2004; Grammatikos, 2008; Klement et al.,
2008; Savu, Potter, Li, \& Yasui, 2008; Weinstock \& Elliott, 2009).

Extensive research has demonstrated that certain food components exert beneficial physiological effects on consumer's health, giving rise to the development of functional foods (Council of the European Union, 2007; Sloan, 1999). Many bioactive compounds (lycopene, polyphenols, unsaturated fatty acids, glucosinolates, proteins, peptides, etc.) have been identified as being responsible for different physiological effects, such as cholesterol-lowering effect, which reduces the risk of

G.H.D. and M.C.A. shared senior authorship.

* Corresponding author. Centro de Investigación y Desarrollo en Tecnología de Alimentos (CIDCA), CONICET-CCT La Plata y Universidad Nacional de La Plata, Calle 47 y 116, 1900 La Plata, Argentina. Tel.: +54 221 4249287; fax: +54 2214254853.

E-mail address: mcacidca@gmail.com (M.C. Añón).

http://dx.doi.org/10.1016/j.jff.2015.12.022

1756-4646/@ 2015 Elsevier Ltd. All rights reserved. 
certain types of cancer and cardiovascular disease, immunomodulation, etc. (Hasler, 2002; Kanu et al., 2007).

The recognition of the role of proteins as physiologically active components is actually increasing. Many foods that contain physiologically active proteins, native or processed, are rich sources of bioactive peptides. Today the most important source of bioactive peptides are milk proteins (Korhonen \& Pihlanto, 2006) and plant proteins (soy, wheat, corn, rice, barley, feed wheat sunflowers, etc.) (Wang \& Gonzalez de Mejia, 2005). In recent years, there has been much interest in studying old crops such as quinoa, amaranth and chia, which were widely used by Incas, Maya and Aztec Civilizations. From the point of view of human health, amaranth contains, either in leaves or seeds, numerous health- and nutritional-beneficial compounds. Besides, and due to the absence of prolamins in the protein composition, amaranth is a functional food alternative for celiac patients. In addition, bioactive phytochemicals (lectins, polyphenols, squalene, saponins, phytates, trypsin inhibitors) (Guzmán-Maldonado \& Paredes-López, 1998) and encrypted peptides endow amaranth grains with functional properties, such as antioxidant, antithrombotic or antidiabetic activities, which make them an attractive option to reduce the risk of certain types of cancer and cardiovascular disease (Barrio \& Añón, 2010; Caselato-Sousa \& Amaya-Farfán, 2012; Fritz, Vecchi, Rinaldi, \& Añon, 2011; Hasler, 2002; Huerta-Ocampo \& Barba de la Rosa, 2011; Kanu et al., 2007; Orsini Delgado, Galeano, Añón, \& Tironi, 2015; Sabbione, Scilingo, \& Añón, 2015; Tironi \& Añón, 2010; Vecchi \& Añón, 2009).

At present, scarce evidence exists about amaranth encrypted peptides with immunomodulatory activity. For this reason, this study was focused on investigating the immunomodulatory effect of components from amaranth grains in the gut.

The intestinal immune system has to strike a delicate balance between initiating inflammatory responses against invading pathogens, and avoiding their induction against microbiota colonising the lumen and food antigens. The gut epithelium forms an essential element of the mucosa as a physical barrier and as an active component of the immune system. Adequate inflammatory responses against bacterial invasion result in the luminal secretion of antimicrobial peptides and the release of cytokines in the tissue to recruit and activate different cell subsets. Thus, intestinal epithelial cells (IEC) play a pivotal role in maintaining gut homeostasis. On the other hand, a highly evolved and robust inflammatory response is induced to changes in the gut microbial community and to "wrongly located" microorganisms. Different inflammatory mediators are known to modulate epithelial integrity and cell activation (Nenci et al., 2007). The transcriptional factor NF$\kappa B$ plays a key role in the cellular response to different stress situations. Extracellular or internal stress signals can activate this pathway and induce the expression of several genes that may be involved in pro-inflammatory processes or for maintaining tissue homeostasis. Bacterial flagellin (FliC) is a key component of the microbiota and a dominant innate immune activator of the intestine through binding to the membrane toll-like receptor 5 (TLR-5) (Yoon et al., 2012) or the cytosolic NLRC4 inflammasome receptors (Zhao et al., 2011).

In this study we analysed the modulation effect of hydrolysates and peptides from amaranth on the FliC-induced NF- $\kappa B$ pathway in intestinal epithelial cells. Our findings indicated that proteins contained in amaranth grains encrypted peptides with anti-inflammatory properties on modulation of CCL20 expression (through the activation of NF- $\mathrm{kB}$ pathway) in activated colonic epithelial cells.

\section{Materials and methods}

\subsection{Materials}

Seeds of Amaranthus hypochondriacus (9122 cultivar) were grown at the Experimental Station of the Instituto Nacional de Investigaciones Agropecuarias (INTA), Anguil (La Pampa, Argentina). Whole seeds were ground in an Udy mill, with a $1 \mathrm{~mm}$ mesh, and were screened using a $0.092 \mathrm{~mm}$ mesh (Facultad de Ciencias Agropecuarias y Forestales, Universidad Nacional de La Plata, Argentina). The flour obtained was defatted with hexane $(10 \%, \mathrm{w} / \mathrm{v})$, air-dried at room temperature, and stored at $4{ }^{\circ} \mathrm{C}$ until used.

\subsection{Preparation and characterisation of amaranth protein isolates (AI)}

The protein isolate was prepared as described previously (Martinez \& Añón, 1996). Briefly, defatted flour was suspended in water and $\mathrm{pH}$ was adjusted to 9. The suspension was stirred ( $30 \mathrm{~min}$ at room temperature) and centrifuged at $9000 \times \mathrm{g}$ $\left(20 \mathrm{~min}\right.$ at $\left.10^{\circ} \mathrm{C}\right)$. The supernatant was precipitated at $\mathrm{pH} 5$ and then separated by centrifugation at $9000 \times \mathrm{g}\left(20 \mathrm{~min}\right.$ at $\left.10^{\circ} \mathrm{C}\right)$. It was suspended in water, neutralised and freeze-dried. Protein content of the isolate determined by the Kjeldahl method was $754.0 \pm 17.3 \mathrm{~g} / \mathrm{kg}(\mathrm{w} / \mathrm{w}, \mathrm{wb})(\mathrm{N} \times 5.85)$. Protein isolates used in this work were prepared at least three times, showing similar properties.

\subsection{Hydrolysis reaction}

The amaranth protein isolate (AI) was dispersed to a final concentration of $10 \mathrm{~g} / \mathrm{L}$ in $35 \mathrm{mM}$ phosphate buffer ( $\mathrm{pH} 7.8$ ) or alkaline water ( $\mathrm{pH} 10)$ and stirred for $1 \mathrm{~h}$ at $37^{\circ} \mathrm{C}$, and incubated with Alcalase (protease from B. licheniformis; Novozyme Corp, Bagsvaerd, Denmark) (80 $\mu \mathrm{L}$ enzyme/g AI) with shaking for $4 \mathrm{~h}$ at $37^{\circ} \mathrm{C}$. Hydrolysis was stopped by heating at $85^{\circ} \mathrm{C}$ during $10 \mathrm{~min}$. The slurry was cooled in an ice bath, frozen, lyophilised and stored at $4{ }^{\circ} \mathrm{C}$ until used. The degree of hydrolysis (DH) was analysed by the trinitrobenzenesulphonic acid (TNBS) method (Adler-Nissen, 1979). Hydrolysates showed a $\mathrm{DH}=23 \%(\mathrm{AH} 23)$ at $\mathrm{pH}$ 7.8\, and $\mathrm{DH}=30 \%(\mathrm{AH} 30)$ at $\mathrm{pH} 10$.

\subsection{Physicochemical characterisation of AI, $\mathrm{AH} 23$ and $\mathrm{AH} 30$}

The protein content, moisture and ash content of hydrolysates were assessed by the Kjeldahl method ( $\mathrm{N}$ 5.85), heating until constant weight, and calcination at $550{ }^{\circ} \mathrm{C}$, respectively. The protein content of the hydrolysate dissolved in Dulbecco modified Eagle medium (DMEM) was analysed by the Micro Kjeldahl method. AI, AH23 and AH30 were also characterised 
by differential scanning calorimetry (DSC), according to the method of Martinez and Añón (1996). Briefly, samples prepared in distilled water $(20: 80, \mathrm{w} / \mathrm{v})$ were placed in aluminium hermetic capsules (10-15 mg of protein). Runs were performed in a Calorimeter TA Q100 V9.8 Build 296 (TA Instruments, New Castle, DE, USA), remained in isotherm at $20^{\circ} \mathrm{C}$ for $2 \mathrm{~min}$, and then a heating rate of $10^{\circ} \mathrm{C} / \mathrm{min}$ between 20 and $140{ }^{\circ} \mathrm{C}$ was used. A sealed double empty capsule was used as a reference. All experiments were conducted in triplicate.

\subsection{Gel electrophoresis}

AI, AH23 and AH30 were analysed by Tricine sodium dodecyl sulphate polyacrylamide gel electrophoresis according to Schägger (2006). Runs were performed using 165, 100 and 40 g/L acrylamide/bisacrylamide for separating, spacing and stacking gels, respectively. Samples were loaded at $20 \mu \mathrm{g}$ of protein per lane. Runs were carried out in a Mini Protean II Dual Slab Cell (BIO-RAD, Hercules, CA, USA). Finally, gels were fixed and stained with Coomassie Brilliant Blue R-250 (1.92 g/L).

\subsection{RP-HPLC chromatography}

Chromatography runs were carried out in a Waters 600E Multisolvent Delivery System equipped with a Water 717 Plus Autosampler and a detector Waters 996 Photodiode Array (Waters Corporation, Milford, MA, USA). AI, AH23 and AH30 were dispersed and incubated during $60 \mathrm{~min}$ at $25^{\circ} \mathrm{C}$ with constant stirring at $650 \mathrm{rpm}$ in Thermomixer comfort (Eppendorf AG, Hamburg, Germany), centrifuged at $9200 \times \mathrm{g}\left(15 \mathrm{~min}\right.$ at $\left.25^{\circ} \mathrm{C}\right)$ (Labnet Digital Spectrafuge 24D, Labnet Int. Edison, NJ, USA), and filtered through $0.45 \mu \mathrm{m}$ membrane pore diameter. Runs were carried out in a SunFire prep C8, 5 Hm ST 10/250 mm preparative column (Waters Corporation) equilibrated with solvent A (98\% water, $2 \%$ acetonitrile, $0.065 \%$ (v/v) trifluoroacetic acid in water) and B (35\% water, $65 \%$ acetonitrile, $0.065 \%(\mathrm{v} / \mathrm{v})$ trifluoroacetic acid in water). Two millilitres of sample $(33.3 \mathrm{mM}$ $\mathrm{K}_{2} \mathrm{HPO}_{4}, 1.7 \mathrm{mM} \mathrm{KH} \mathrm{PO}_{4}, \mathrm{pH}$ 7.8) were injected. Samples were eluted during the first $3 \mathrm{~min}$ with solvent $\mathrm{A}$ and then with $\mathrm{a}$ linear gradient of solvent A to B, from 0 to $100 \%$ in $55 \mathrm{~min}$ at a flux rate of $5.2 \mathrm{~mL} / \mathrm{min}$. Separation was carried out at $35^{\circ} \mathrm{C}$. Detection was performed at 210 and $280 \mathrm{~nm}$. Fractions (0.6 min) were collected automatically in 5 runs, 80 fractions (M1-M80) were collected and freeze-dried. Samples M1 and M2 obtained from AH30 were dispersed and incubated as previously indicated. Fifty microlitres of samples were injected in an analytical column Sephasil Peptide C8, $12 \mu \mathrm{m}$ ST 4.6/250 (Amersham Pharmacia Biotech, Uppsala, Sweden), eluted with solvent gradient and manually collected. We obtained 15 fractions (F1F15) in 3 runs, which were pooled and freeze-dried.

\subsection{Nano-chromatography/mass spectrometry}

Fractions (F6, F9, F12, F13 and F14) were analysed by liquid chromatography (UHPLC to the nano scale) with the UltiMate ${ }^{8} 3000$ RSLC-nano system (Dionex, Thermo Fisher Scientific Inc., Breda, The Netherlands), and analysed by mass spectrometry with the ESI-ORBITRAP Velos (Thermo Fisher Scientific Inc., Carlsbad, CA, USA). Chromatographic separation was performed on a reverse-phase capillary column: Acclaim PepMap RSLC column,
C18, $2 \mu \mathrm{m}$ particle size, 100A pore size, $75-\mu \mathrm{m}$ i.d. $\times 15-\mathrm{cm}$ length (Dionex, Thermo Fisher Scientific), and a pre-column: Acclaim PepMap 100 nano-trap column, C18, $5 \mu \mathrm{m}$ particle size, 100A pore size, $100-\mu \mathrm{m}$ i.d. $\times 2$-cm length (Dionex) equilibrated with solvent A (99\% water, $1 \% \mathrm{HCOOH})$ and B (10\% water, $90 \%$ acetonitrile, $0.08 \%$ (v/v) $\mathrm{HCOOH}$ ). Samples were eluted with a linear gradient of solvent $\mathrm{A}$ to $\mathrm{B}, 4$ to $50 \%$ in $30 \mathrm{~min}$ at a flux rate of $300 \mathrm{~nL} / \mathrm{min}$. Mass-spectrometry analysis was conducted in the platform "Biopolymers-Structural Biology," located at the INRA Center of Angers (http://centres.inra.fr) (Nantes, France). We detected 16 different peptides.

\subsection{Identification of peptides and in silico analysis}

\subsubsection{Multiple sequence alignments}

The EMBOSS Needle (European Molecular Biology Open Software Suite) software was used (with a BLOSUM62 matrix and the rest in terms of default) (http://www.ebi.ac.uk/Tools/ psa/emboss_needle/).

\subsubsection{Protein databank identification-searching}

In order to find homologous sequences between the synthesised peptides and peptides from the NCBI database restricted to green plant sub-kingdom (Viridiplantae), we used the BLAST (Basic Local Alignment Search Tool) software (matrix BLOSUM62, database Non-redundant protein sequences, algorithm BLASTP) (http://blast.ncbi.nlm.nih.gov).

\subsection{Synthesis of peptide 2, peptide 3 and peptide 5}

Selected peptides were synthesised using the ABC technique Solid phase peptide synthesis (SPPS), developed by China Peptides Co. (Shanghai, China). Peptide purity was $>98 \%$. Peptide 5 (KPV) was synthesised as a control modulator peptide of the immune response (Dalmasso et al., 2008).

\subsection{Cell culture}

We used the human colon carcinoma cell lines Caco-2 and Caco-2 ccl20:luc (cell line transfected with a luciferase reporter construction under the control of CCL20 promoter); the cell lines were kindly provided by Dr. Rumbo (Nempont et al., 2008). Cells were grown in DMEM supplemented with $15 \%$ foetal bovine serum, $10 \mathrm{IU} / \mathrm{mL}$ penicillin and $100 \mu \mathrm{g} / \mathrm{mL}$ streptomycin, and further cultured with FliC from Salmonella typhimurium $(1.5 \mu \mathrm{g} / \mathrm{mL})$ at $37^{\circ} \mathrm{C}$ in a humidified atmosphere containing $5 \%$ $\mathrm{CO}_{2}$.

\subsection{Reporter gene expression assays}

Caco-2 ccl20:luc cells were incubated with FliC $(1.5 \mu \mathrm{g} / \mathrm{mL})$ during $4 \mathrm{~h}$ at $37^{\circ} \mathrm{C}$ in supplemented DMEM medium. Cells were treated with lysis buffer (25 mM Tris-phosphate, $2 \mathrm{mM}$ dithiothreitol (DTT), 2 mM 1,2-diaminocyclohexane-N,N,Ń,N-tetraacetic acid, $10 \%$ glycerol and 1\% Triton X-100) and luciferase activity was measured using the luciferase substrate (Luciferase assay kit, Promega, Madison, WI, USA) following the manufacturer's instructions. Light emission was measured with a luminometer (Luminoskan TL Plus; Thermo Fisher Scientific Inc.). Lumines- 
cence was expressed as percentage of the normalised average luminescence (\% NAL)

$\% \mathrm{NAL}=\mathrm{L}_{\mathrm{x}} / \mathrm{L}_{\mathrm{FliC}} \times 100$

$\mathrm{L}_{\mathrm{x}}=$ luminescence of FliC-activated cells incubated with hydrolysates or peptide

$\mathrm{L}_{\text {Flic }}=$ luminescence of FliC-activated cells plus medium

\subsection{Quantitative real-time RT-PCR}

Caco- 2 cells were incubated with FliC $(1.5 \mu \mathrm{g} / \mathrm{mL})$ or different hydrolysates for $2 \mathrm{~h}$. Cells were collected, and total RNA was isolated using the illustra RNAspin mini isolation kit according the manufacturer's specifications (GE Healthcare, Buckinghamshire, UK). The quality of the extracted RNA was determined by UV absorption and the optical density (OD) ratio of $\mathrm{OD}_{280 \mathrm{~nm}} / \mathrm{OD}_{260 \mathrm{~nm}}$ was used as a purity marker. A complementary DNA (cDNA) preparation was obtained from $1 \mu \mathrm{g}$ of RNA using M-MLV reverse transcriptase and random primers (Invitrogen, Life Technologies, Carlsbad, CA, USA). Chemokine mRNA expression was determined by real-time quantitative PCR. The experimental procedure was performed with the ABI PRISM sequence detection system using SYBRGreen fluorescence (BioRad, Buenos Aires, Argentina). The sequences of the primers were designed with the Perlprimer software using nucleotide sequences present in a GenBank database.

$\beta$-actin was used as a house-keeping gene to standardise the total amount of CDNA, and the chemokine ligand-20 (CCL20) was analysed to study cell activation. Relative mRNA levels $\left(2^{\Delta \mathrm{Cts}}\right)$ were determined by comparing the PCR cycle threshold between cDNA of the gene of interest and that of $\beta$-actin (Cts), and the Cts values between treated and untreated conditions ( $\Delta \mathrm{Cts}$ ).

\subsection{Cytotoxicity assays}

\subsubsection{Neutral red assay (NR)}

The neutral red accumulation assay was performed according to Borenfreund, Babich, and Martin-Alguacil (1988). A total of $2.5 \times 10^{5}$ cells $/ \mathrm{mL}$ were plated in 48 -well tissue plates and treated with medium or AI, AH23, AH30, M1, M2 and synthetic peptides 2, 3 and 5 during $4 \mathrm{~h}$ at $37{ }^{\circ} \mathrm{C}$ in $5 \% \mathrm{CO}_{2}$ atmosphere. $\mathrm{OD}_{550}$ was measured in a Multi-Detection Microplate Synergy HT (BioTek Instruments, Inc., Winooski, VT, USA), and the percentage of retention of NR was expressed as:

$\% \mathrm{NR}=\left(\mathrm{NR}_{\mathrm{x}} / \mathrm{NR}_{(-)}\right) \times 100$

$\mathrm{NRx}=$ optical density of treated cells and $\mathrm{NR}_{(-)}$ = optical density of untreated cells considered as $100 \%$ viability

2.13.2. 3-(4,5-dimethylthiazol-2-yl)-2,5-diphenyltetrazolium bromide (MTT) assay: colorimetric assay for assessing the mitochondrial dehydrogenase activity

The assay was performed as previously described by Mosmann (1983). Briefly, $2.5 \times 10^{5}$ cells $/ \mathrm{mL}$ were plated in 48 -well dish plate and treated with medium or AI, AH23, AH30, M1, M2 and the synthesised peptides at several concentrations for $2 \mathrm{~h}$ at $37^{\circ} \mathrm{C}$ in $5 \% \mathrm{CO}_{2}$ atmosphere. Tetrazolium dye was added and $\mathrm{OD}_{570}$ corresponding to the metabolite formazan was measured. The percentage of mitochondrial activity (MTT) was expressed as

$\% \mathrm{MTT}=\left(\mathrm{MTT}_{\mathrm{x}} / \mathrm{MTT}_{(-)}\right) \times 100$

MTTx $=$ optical density of treated cells and $\mathrm{MTT}_{(-)}$ = optical density of untreated cells considered as $100 \%$ viability

2.13.3. Lactate dehydrogenase assay (LDH)

Cell death was assessed by detecting the intracellular enzyme LDH in the supernatant with a colorimetric assay. Briefly, $2.5 \times 10^{5}$ cells $/ \mathrm{mL}$ were plated in a 48-well dish and treated with medium or AI, AH23, AH30, M1, M2 and the synthetic peptides at different concentrations for $24 \mathrm{~h}$ at $37^{\circ} \mathrm{C}$ in $5 \% \mathrm{CO}_{2}$ atmosphere. Supernatants were collected and cells were centrifuged and further lysed with $0.1 \%$ (v/v) Triton X-100 (Sigma Chemical Co., St. Louis, MO, USA). The LDH enzymatic activity was assessed with the commercial LDH-P kit (Wiener Lab., Rosario, Argentina). Results were calculated as follows:

\section{\% LDH = LDH activity in supernatant/ \\ LDH activity in cell lysate $\times 100$.}

\subsection{Statistical analysis}

Multifactor analysis of variance (ANOVA) was done by means of GraphPad Prism, a software package (GraphPad Software Inc., La Jolla, CA, USA). Tukey's test was used to compare the means of the different variables. $P$ values $<0.05$ were considered significant. Results were the mean of at least two independent measurements.

\section{Results}

\subsection{Physicochemical characterisation of amaranth isolates and hydrolysates}

We initially investigated the physicochemical characteristics of AI, AH23 and AH30 (Table 1). The protein content of the different samples varied between 75.4 and $51.2 \%$, while ash content varied between 3.2 and $27.4 \%$, depending on the grade of hydrolysis.

As seen in Table 1, solubility in DMEN increased with the hydrolysis showing a good solubility in a cell culture medium.

The polypeptide profile of AI, AH23 and AH30 as determined by Tricine-SDS-PAGE under reducing conditions (Fig. 1) was similar for samples dissolved in water or in DMEN. AI showed a high content of the polypeptides from the globulin fraction: $11 \mathrm{~S}$ globulin, acidic polypeptides $(33 \mathrm{kDa})$ and basic polypeptides (18-23 kDa), globulin-P, polypeptides (54-56 kDa) and 7S globulin polypeptides (40-42 kDa). Soluble aggregates of $64 \mathrm{kDa}$ and $66-98 \mathrm{kDa}$ and polypeptides from the albumin fractions (less than $18 \mathrm{kDa}$ ) were also detected. AH23 showed 
Table 1 - Physicochemical characteristics of AI, AH23, AH30 samples.

\begin{tabular}{lccc} 
Physicochemical properties & AI & AH23 & AH30 \\
\hline Degree of hydrolysis (DH\%) & - & $22.81 \pm 0.38$ & $30.30 \pm 1.11$ \\
Soluble protein in DEMEN (\%) (mg soluble protein/mg total protein).100 & $63.20 \pm 1.40$ & $91.85 \pm 0.58$ & $87.60 \pm 5.26$ \\
Sample protein (\%) (mg protein/mg wet sample).100 & $75.40 \pm 1.73$ & $51.02 \pm 0.47$ & $68.40 \pm 0.15$ \\
Td of proteins ( $\left.{ }^{\circ} \mathrm{C}\right)$ & $72.84 \pm 0.06 \mathrm{a}$ & $68.33 \pm 0.20 \mathrm{a}$ & $68.22 \pm 0.35 \mathrm{a}$ \\
Denaturation temperature & $101.33 \pm 0.03 \mathrm{~b}$ & $101.69 \pm 0.76 \mathrm{~b}$ & $99.93 \pm 4.03 \mathrm{~b}$ \\
DE of proteins (J/g) & $1.66 \pm 0.25 \mathrm{a}$ & $0.19 \pm 0.03 \mathrm{a}$ & $0.21 \pm 0.05 \mathrm{a}$ \\
Enthalpy of denaturation/g protein & $4.00 \pm 0.76 \mathrm{~b}$ & $1.38 \pm 0.05 \mathrm{~b}$ & $1.23 \pm 0.02 \mathrm{~b}$ \\
Humidity (\%) (mg protein/mg sample).100 & $7.13 \pm 0.17$ & $9.49 \pm 0.02$ & $8.06 \pm 0.09$ \\
Ash (\%) (mg ash/mg sample).100 & $3.33 \pm 0.18$ & $27.04 \pm 0.18$ & $6.03 \pm 0.13$ \\
pH & $7.0 \pm 0.1$ & $7.8 \pm 0.1$ & $10.0 \pm 0.1$ \\
\hline a, b: Td and DE values with different letters have statistically significant differences (p<0.05). Results are expressed as mean \pm SD.
\end{tabular}

the presence of a faint band at $64 \mathrm{kDa}$ corresponding to the 7S globulin, 3 bands in the region of $18-23 \mathrm{kDa}$ corresponding to different basic 7S and 11S globulins, which are the more resistant to enzymatic hydrolysis, and a $37 \mathrm{kDa}$-band and bands in the region of 14-17 kDa corresponding to hydrolysis products. Finally, AH30 revealed no bands corresponding to the $11 \mathrm{~S}$ globulin basic polypeptides, while the region corresponding to the hydrolysis products ( $37 \mathrm{kDa}$ and $23-26 \mathrm{kDa}$ ) exhibited a higher intensity compared to the other hydrolysates. The smallsized peptides, products of the hydrolysis, were not retained in the gel matrix.

Regarding the thermodynamic parameters analysed, the AI exhibited two denaturation endotherms with peak temperatures of $72.84 \pm 0.06$ and $101.33 \pm 0.03^{\circ} \mathrm{C}$, respectively (Table 1). The enthalpy associated to the process was $4.00 \pm 0.76 \mathrm{~J} / \mathrm{g}$ of protein. The hydrolysis treatment modified the AI proteins as evidenced by the presence of a single endotherm of lower thermal stability and denaturation heat $(1.38 \pm 0.05$ and $1.23 \pm 0.02 \mathrm{~J} / \mathrm{g}$ of protein of $\mathrm{AH} 23$ and $\mathrm{AH} 30$, respectively), suggesting that the hydrolysis process introduced conformational changes retaining only a small proportion of the original structure.

\subsection{Characterisation of the inhibitory properties of the protein hydrolysates}

We investigated the inhibitory effect of the protein extract of amaranth and different hydrolysates on activated human epithelial cells (Fig. 2). For inhibition assays Caco-luc cells were pre-incubated with different concentrations of samples and then exposed to FliC for $4 \mathrm{~h}$. We found that the TLR-5-dependent luciferase induction was inhibited with neither AI nor $1 \mathrm{mg} /$ mL. However, a significant suppression of light emission was achieved with $2.5 \mathrm{mg} / \mathrm{mL}$ and $5.0 \mathrm{mg} / \mathrm{mL}$ (data not shown) of $\mathrm{AH} 23$ and $\mathrm{AH} 30$ in a dose-response manner (Fig. 2A). In addition, we also assessed the inhibitory effect of hydrolysates on Caco-luc cells at different times of pre-incubation; after washing the cells, we observed that FliC activation was suppressed irrespective of the duration of pre-incubation step (Fig. 2B). These findings clearly indicate that components of hydrolysates exerted the inhibitory effect on resting cells that were further activated.

The metabolic status of Caco-luc cells following the incubation with the hydrolysates was analysed by LDH, RN and MTT assays (Fig. 2C). We found that $2.5 \mathrm{mg} / \mathrm{mL}$ of hydrolysates were

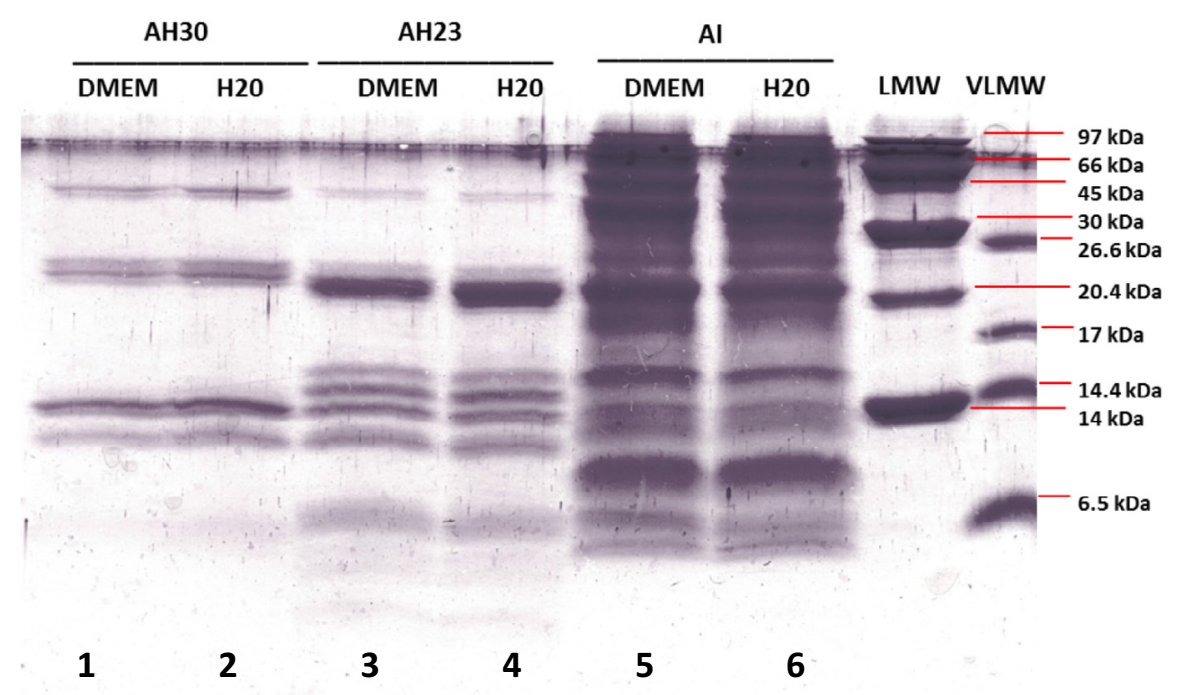

Fig. 1 - Electrophoretic patterns of AH30, AH23 and AI dissolved in DMEN (lanes 1, 3, 5) and water (lanes 2, 4, 6). Lanes 7 and 8 correspond to low and very low molecular mass standards (LMW and VLMW). Td and Hd values with idfferent letters have statistically significat differences $(p<0.05)$. Values are expressed as the mean \pm MD. 

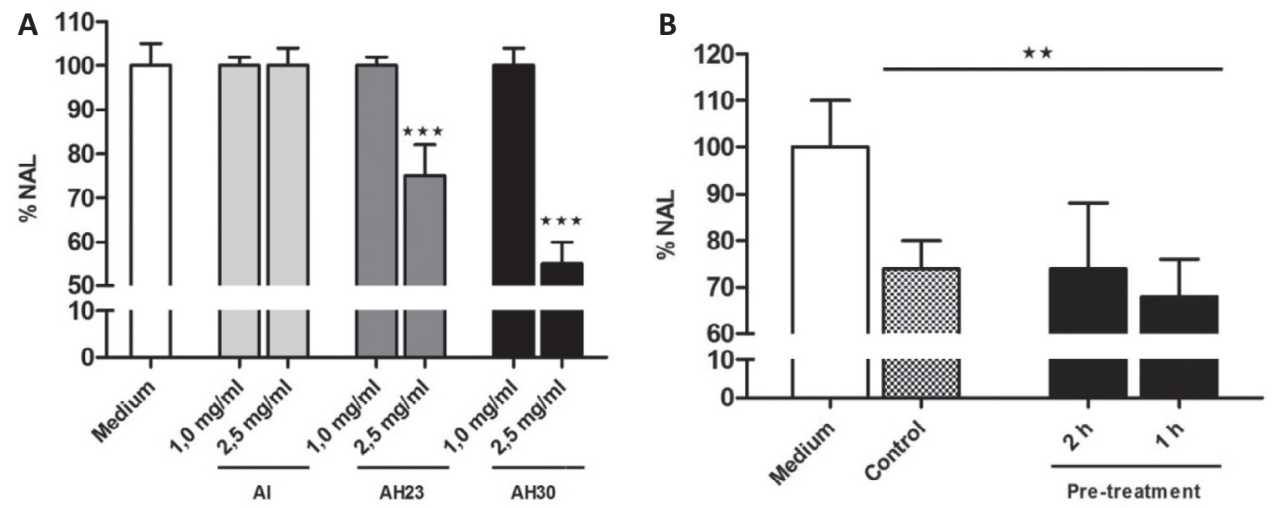

C

a) Al

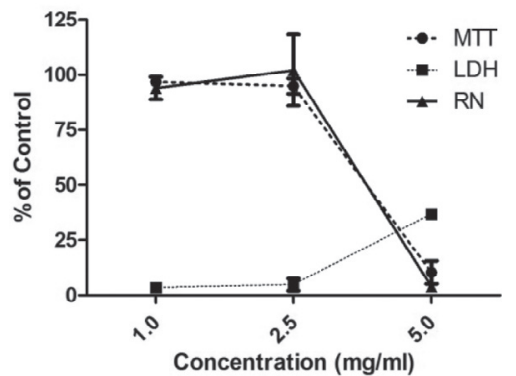

b) $\mathbf{A H} 23$

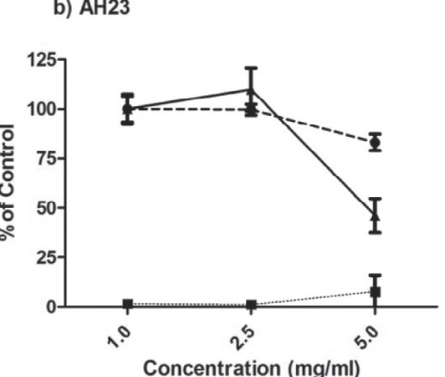

c) $\mathrm{AH} 30$

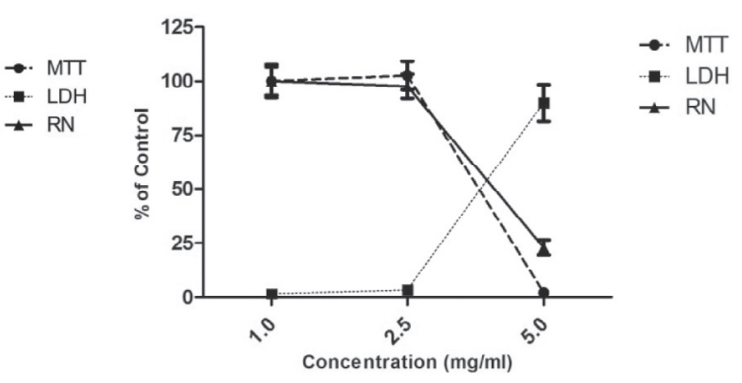

Fig. 2 - Inhibitory properties of AI, AH23 and AH30 on activated Caco-luc cells. Normalised average luminescence (NAL) was assessed with different concentrations of Amaranth samples that were co-incubated with FliC. FliC control corresponds to activated cells (A); \% NAL in AH30-pre-incubatd Caco-luc cells at different times (1 and 2 hours) and further activated with FliC. FliC control corresponds to FliC-activated cells and Control corresponds to FliC-activated cells co-incubated with AH30 (B); and toxicity effect of different amounts of AI, AH30 and AH23 on Caco-luc cells analysed by RN (A), LDH ( $\square$ ) and MTT (O) assays (C). Experiments were performed three times and samples were analysed in duplicate. Data are expressed as mean values \pm standard error of the mean $(\mathrm{SEM})\left({ }^{* * *} \mathrm{P}<0.001,{ }^{* *} \mathrm{P}<0.01\right)$.

non-toxic, while $5 \mathrm{mg} / \mathrm{mL}$ were toxic for cells (decreased MTT and NR, and increased LDH).

\subsection{Chromatographic analysis of hydrolysates and characterisation of eluates}

Protein hydrolysates were fractioned by HPLC and grouped in three fractions: 1 hydrophilic, 2 intermediate and 3 hydrophobic (Fig. 3A and B). Fractions eluated were evaluated for their inhibitory effect on Caco-luc cells. Fraction 1 contained hydrophilic components and eluates M1 and M2 exerted the strongest cell inhibition (Fig. 3C) in a dose-response manner (Fig. 3D): $1.112 \pm 0.082 \mathrm{mg} / \mathrm{ml}$ protein of M1 and $2.505 \pm 0.091 \mathrm{mg} /$ $\mathrm{ml}$ of $\mathrm{M} 2$ exerted the maximum inhibition of FliC-induced cell activation ( $81.13 \pm 1.82 \%$ and $98.91 \pm 0.47 \%$, respectively) (Fig. 3D). These eluated were non-toxic at the maximum concentration (Fig. 3E).

In order to identify individual components with biological properties, we fractioned M1 and M2 eluates by HPLC (Fig. 4A). Then, 5 fractions of M2 that showed a marked suppression of activated Caco-luc cells (Fig. 4B and C) were analysed. The analysis of these fractions by UHPLC/ESI-MS identified 16 peptides (Table 2).

\subsection{Characterisation of peptides}

Bioinformatic tools were used to investigate whether peptides identified by sequencing possessed a potential immunomodulatory activity. Sequences of the 16 peptides were aligned with that of immunomodulatory peptides included in the BIOPEP database (http://www.uwm.edu.pl/biochemia/ index.php/pl/biopep) using the software Needle EMBOSS. According to the analysis performed, the two peptides showing the best alignments were selected and synthesised: Peptide 2 (fraction 12, Table 2): SSEDIKE (4/0) score 17.0, aligned with the RETIESLSSSEESIPEYK peptide belonging to the human protein $\beta$-casein, and Peptide 3 (fraction 14, Table 2): IADEDPDEANDK $(3 / 0)$ score 17.0 , aligned with the DSDPR peptide with inhibitory action on IgE-mediated hypersensitivity.

Furthermore, Peptide 1 (fraction 9, Table 2) LENAIDKK (3/ 0) score 10.0 aligned with sequences of homologous proteins of amaranth (maturase $\mathrm{K}$ (chloroplast), Amaranthus praetermissus) included in NCBI database restricted to the green plant subkingdom, with high statistic significance (100\% identities, e-4e04 value). Besides, we selected an additional peptide with a consensus sequence resulting from multiple alignments of the sequenced peptides inter and intra-groups, using the ClustalW2 

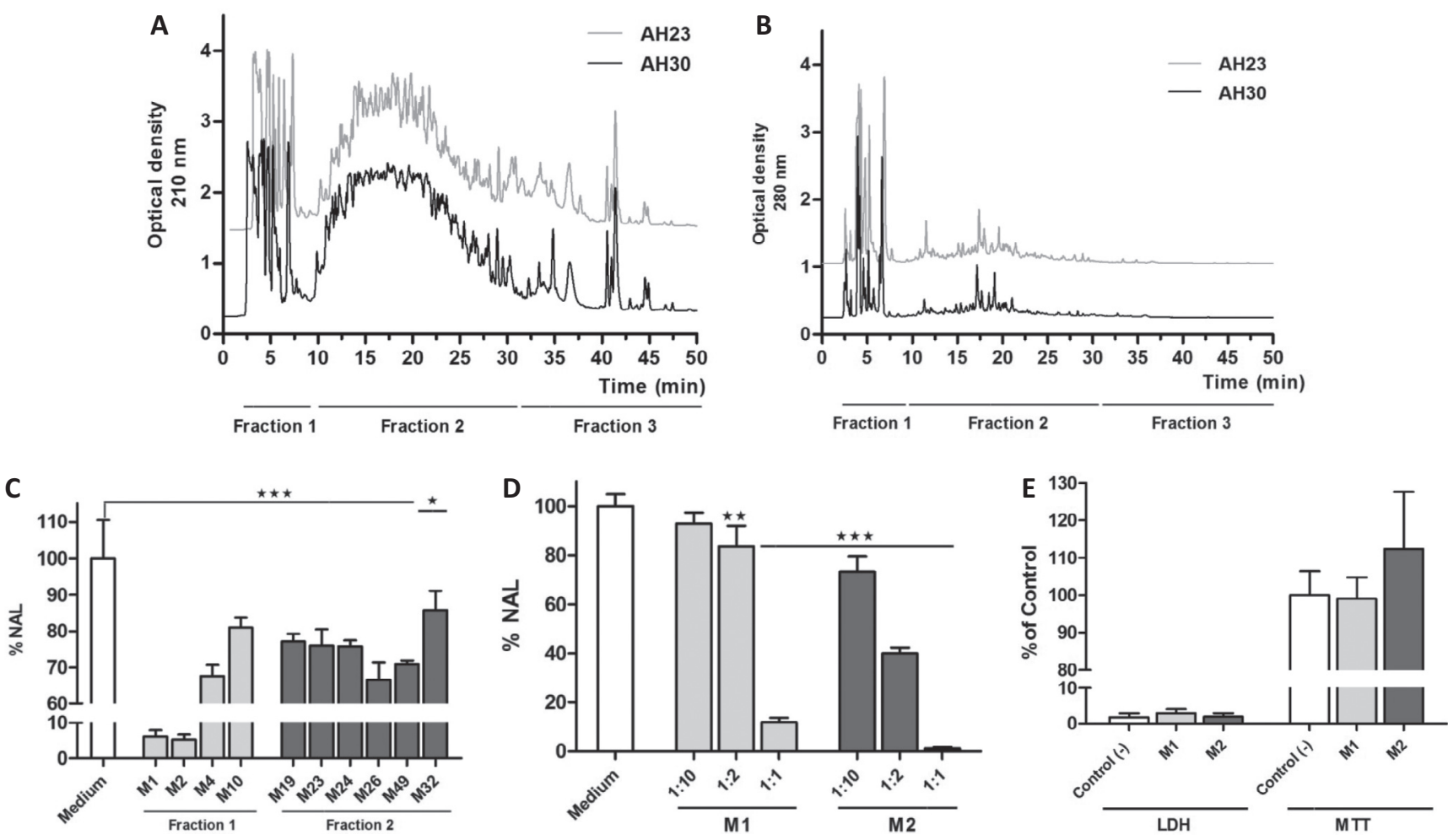

Fig. 3 - Chromatographic separation of AH30 and AH23 and characterisation of eluates. HPLC chromatogram of AH30 and AH20 at 210 (A) and $280 \mathrm{~nm}$ (B). \% NAL of fractions 1 and 2 (C), and M1 and M2 at different concentrations (D). FliC control corresponds to FliC-activated cells. Toxicity effect of M1 $(1.11 \mathrm{mg} / \mathrm{mL})$ and M2 $(2.55 \mathrm{mg} / \mathrm{mL})$ on Caco-luc cells analysed by LDH $(\square)$ and MTT $(\Theta)$ assays (E). Experiments with cells were performed three times and samples were analysed in duplicate. Data are expressed as mean values \pm standard error of the mean (SEM) $\left({ }^{* * *} \mathrm{P}<0.001,{ }^{* *} \mathrm{P}<0.01,{ }^{*} \mathrm{P}<0.05\right)$.

software (http://www.ebi.ac.uk/Tools/msa/clustalw2/). We found that Peptide 4 (DNDEE) presented the best alignment with the highest score, from the set of peptides KEISDDEDEE intergroup (fraction 12, Table 2), GKVEDVDEE (fraction 14, Table 2), AVRNDDE (fraction 6, Table 2) and EALNDEE (fraction 13, Table 2). Finally, we selected the KPV peptide (Peptide 5), reported as a peptide with immunomodulatory properties (Dalmasso et al., 2008).

These 5 peptides were synthesised and their inhibitory potencies were analysed with the reporter Caco-luc cells (Fig. 5A). While peptides 1 and 4 showed no significant inhibitory activity (data not shown), peptides 2, 3 and 5 suppressed cell activation (Fig. 5A). In addition, we found that Caco-luc cells pre-incubated with a combination of peptides at different concentrations rendered a significant inhibition with $200 \mu \mathrm{g} / \mathrm{mL}$ of peptides 2 and 3. Similar inhibitions were obtained with $200 \mu \mathrm{g} / \mathrm{mL}$ of peptide 3 and peptide 5 (KPV). When peptides were combined at $100 \mu \mathrm{g} / \mathrm{mL}$, we observed a synergistic inhibitory effect with peptides 2 and 3. No clear synergistic effect was observed with peptides at $200 \mu \mathrm{g} / \mathrm{mL}$, thus suggesting that receptors can be saturated. In addition, toxicity was assessed with LDH, MTT and NR assays (Fig. 5B), and we found that the active peptides 2, 3 and 5 were non-toxic for cells.

We finally quantified the inhibitory effect of peptides on CCL20 gene expression by qPCR in Caco-2 cells (Fig. 5C). We observed significant gene suppression with 100 and $200 \mu \mathrm{g} /$ $\mathrm{mL}$ of P2 (SSEDIKE) and P5 (KPV).

\section{Discussion}

Intestinal epithelial cells have a critical role in the management of exogenous antigens that contact the apical side, and the immune system that faces the basolateral side. The intracellular signalling that is continuously switched on and off in these cells is intimately involved with the ability to induce protective immunity against pathogens while maintaining tolerance towards the microbiota and innocuous antigens. Cell-cell contact interactions and soluble pro- and anti-inflammatory factors (IL-1 $\beta$, IL-8, MCP-1, IL-10, TSLP, etc.) mediate these effects. In this work we used the Caco- 2 cell line to study the effect of different activators and modulators of the immune response (Bandyopadhaya \& Chaudhuri, 2009; Smaldini, Stanford, Romanin, Fossati, \& Docena, 2013). This cell line produces CCL20 to recruit immature dendritic cells and $\mathrm{T}$ lymphocytes to mucosal target sites, through the activation of the NF- $\kappa$ B pathway (Ito, Carson, Cavassani, Connett, \& Kunkel, 2011). This family of transcription factors is known to play a key role in promoting the expression of cytokines and chemokines. In this study, we used protein extracts, hydrolysates and peptides from amaranth to investigate the modulation of the early steps of intestinal epithelial cell activation. Once cells are activated through the engagement of TLR5, p65 (a NF- $\mathrm{kB}$ component) is translocated into the nucleus within 30 minutes, and then CCL20 is secreted in hours (Kao et al., 2005; Soboll, 

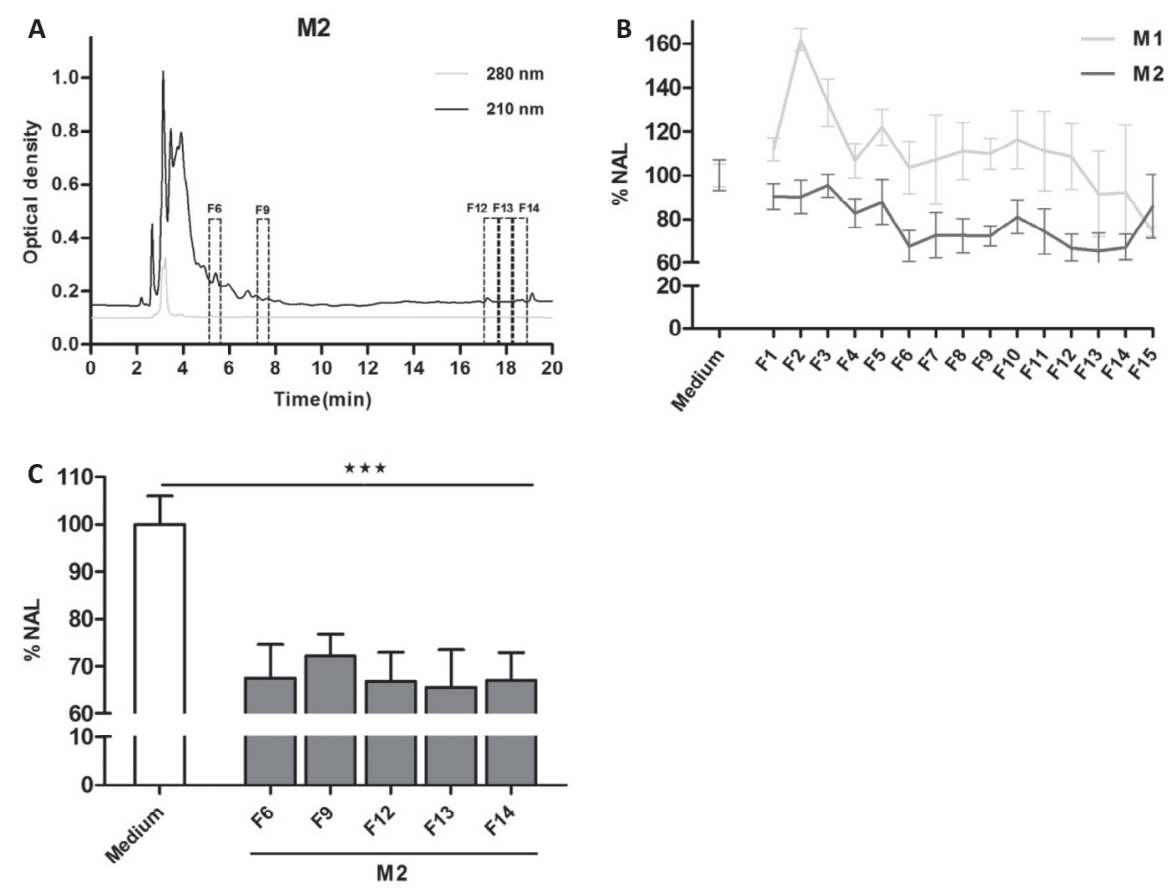

Fig. 4 - Chromatographic separation of M1 and M2 and characterisation of eluates. HPLC chromatogram of M1 and M2 at 210 (A). \% NAL of different fractions of M1 and M2 (B) and five selected fractions of M2 (C). FliC control corresponds to FliCactivated cells. Experiments with cells were performed twice and samples were analysed in duplicate. Data are expressed as mean values \pm standard error of the mean (SEM) $\left({ }^{* * *} \mathrm{P}<0.001,{ }^{*} \mathrm{P}<0.05\right)$.

Crane-Godreau, Lyimo, \& Wira, 2006). Our findings showed the existence of encrypted peptides in amaranth proteins endowed with anti-inflammatory properties. The inhibitory capacity of the hydrolysates to modulate the FliC-mediated activation of epithelial cells was higher compared with that of nonhydrolysed isolates, suggesting that the enzymatic hydrolysis released specific peptides with inhibitory properties. This effect was confirmed using synthetic peptides, which were in silico selected among active fractions of hydrolysates. The alignment analysis of sequences included the use of a database containing known immunomodulatory peptides.

Table 2 - Peptide sequences identified in fraction M2

\begin{tabular}{ll} 
Fractions & Peptides \\
\hline F6 & AVRNDDE \\
F9 & LENAIDKK \\
F12 & SIDEDAGE \\
& KEISDDEDEE \\
& MADVQMAEAE \\
& SSEDIKE \\
F13 & EGGDEIKE \\
& DDGADEIK \\
& ISDDEDDEPK \\
F14 & EALNDEE \\
& IADEDPDEANDK \\
& IADEDPDEANDKDK \\
& GKVEDVDEE \\
F9, F12, F13 & QDDGADEIK \\
F12, F13, F14 & LENAIDK \\
& ISDDEDDEPKKE \\
\hline
\end{tabular}

It is known that IEC bear at the apical membrane oligopeptide transporters for the absorption of small diet peptides (Liang et al., 1995). These peptide transporters have been thoroughly characterised in chronically inflamed colon (Merlin et al., 2001) and in the Caco-2 cell line (Adibi, 1997). Here, we demonstrated that resting IEC have the capacity to recognise hydrophilic amaranth peptides. Pre-incubation of Caco-2 cells with hydrolysates or synthetic peptides suppressed the further activation with FliC, which suggests that receptors are expressed in the membrane prior to activation. Besides, we observed a concentration-dependent inhibition of light emission and CCL20 expression on FliC-activated epithelial cells, and a synergistic effect with combined peptides (P2 - SSEDIKE, P3 - IADEDPDEANDK and control P5 - KPV) depending on their concentration. These findings indicate that receptors can be saturated.

In this study, we used FliC as cell stimulator to mimic the scenario of inflammatory bowel diseases (Lodes et al., 2004). It has been demonstrated that in this chronic intestinal inflammatory disorder, bacterial flagellin from the microbiota activates innate immunity (Barnes \& Karin, 1997) with an aberrant NF- $\kappa \mathrm{B}$ activation, and CCL20 over-expression (Desreumaux, 2004). The KPV control peptide and other related peptides with anti-inflammatory properties were in vivo and in vitro employed in a colitis model by others (Bettenworth et al., 2011; Brzoska, Luger, Maaser, Abels, \& Böhm, 2008; Dalmasso et al., 2008; Kannengiesser et al., 2008). They demonstrated on colonic epithelial cells that peptides stabilised the intestinal barrier function and attenuated experimental inflammation. In this sense, further studies are mandatory to address the question whether peptide transporters are equally expressed in IEC 

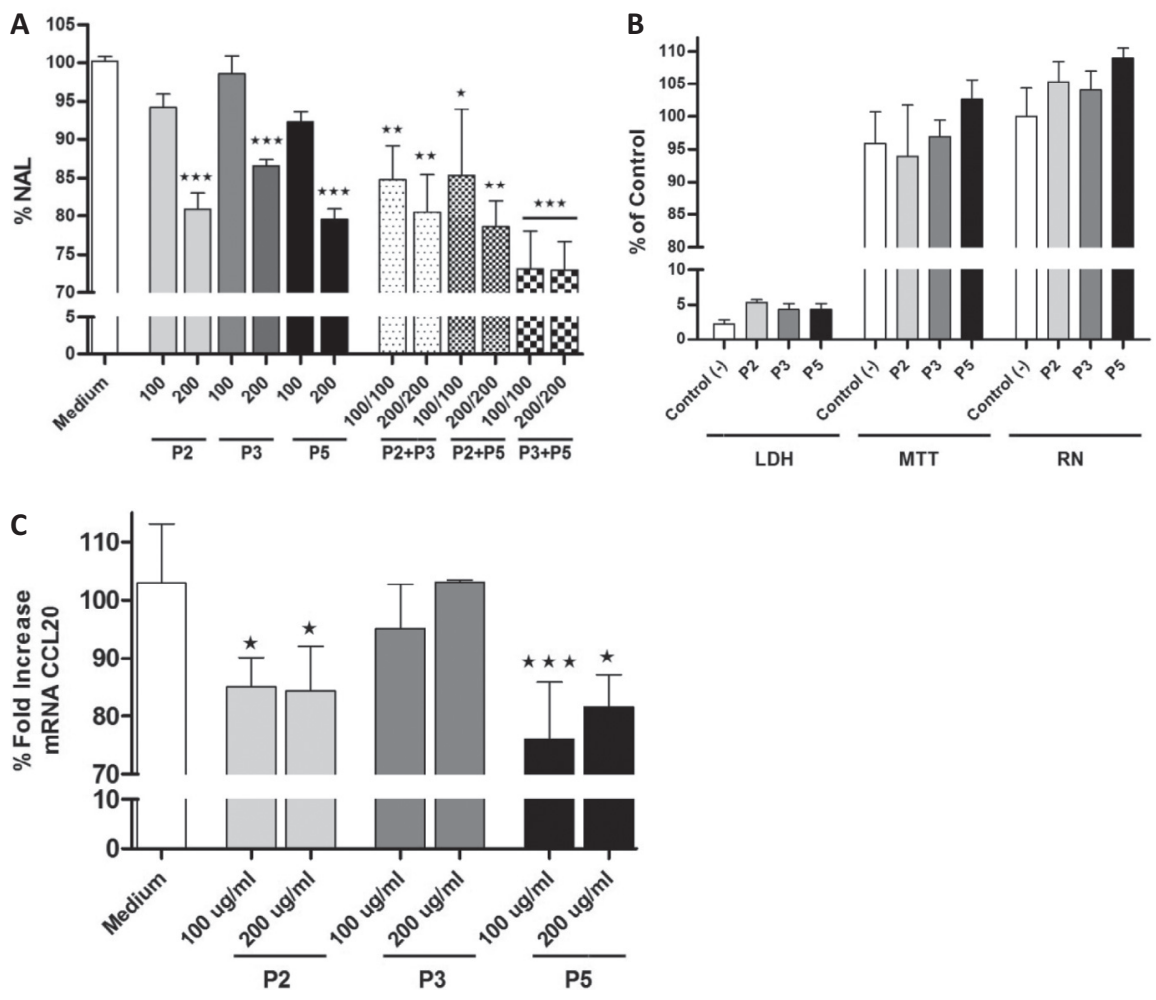

Fig. 5 - Inhibitory properties of synthesised peptides on activated Caco-luc cells. \% NAL of peptide 2, 3 and KPV (peptide 5) at different concentrations and combinations. FliC control corresponds to FliC-activated cells. (A). Toxicity effect of peptides 2, 3 and 5 on Caco-luc cells analysed by RN, LDH and MTT (B). Effect of different amounts of peptides 2, 3 and 5 on CCL20 gene expression in Caco-2 cells by RT-qPCR (C). Fold increase of gene expression normalised according to $\beta$-actin expression, relative to the basal expression of CCL20 in resting cells. Experiments with cells were performed three times and samples were analysed in duplicate. Data are expressed as mean values \pm standard error of the mean (SEM) $\left({ }^{* * *} \mathrm{P}<0.001,{ }^{* *} \mathrm{P}<0.01,{ }^{*} \mathrm{P}<0.05\right)$. CCL20 gene expression was performed four times and quantitative real-time RT-PCR in duplicate. Data are expressed as mean values \pm standard error of the mean (SEM) $\left({ }^{* * *} P<0.001,{ }^{*} P<0.05\right)$.

isolated from colon of IBD patients. If so, we could speculate to use amaranth peptides in functional foods in healthy and disease. Besides, the concentration-dependent inhibition of light emission and CCL20 expression on FliC-activated epithelial cell, and the synergistic effect mainly observed with $100 \mu \mathrm{g} / \mathrm{mL}$ of combined peptides (P2 - SSEDIKE, P3 - IADEDPDEANDK or control P5 - KPV), suggested that receptors can be saturated. Although P3 was effective in combination with P2 and KPV to inhibit light emission, this effect was not reflected at the CCL20 gene expression level when used alone with activated Caco-2.

In this study, we provided evidence that SSEDIKE peptide (peptide 2), alone or in combination with P3 or KPV (P5), showed an anti-inflammatory activity, and although the precise underlying mechanism remains to be confirmed it was indirectly shown that NF- $\kappa B$ pathway was down-modulated. In a recent study, it has been shown that Amaranth hypochondriacus hydrolysates, obtained by the action of pepsin and pancreatin enzymes, inhibited the inflammatory process induced by LPS in human and mouse macrophages. According to these authors, amaranth peptides inhibited the NF- $\kappa B$ signalling pathway leading to a reduction in the nuclear expression of p50 and p65 NF-kB subunits, and the expression of COX-2 and iNOS (Montoya-Rodriguez, Gonzalez de Mejia, Dia, Reyes-Moreno, \&
Milan-Carrillo, 2014). The literature reflects that the antiinflammatory properties of peptides encrypted in food proteins have been mostly studied in this type of systems (Dia, Wang, Oh, de Lumen, \& Gonzalez de Mejía, 2009; Hernandez-Ledesma, Hsieh, \& de Lumen, 2009).

\section{Conclusions}

The soluble peptides from amaranth exerted anti-inflammatory effects in colonic epithelial cells, and this effect might be receptor-mediated. These results indicated that peptides reducedCCL20 production by mucosal and immune cells and therefore raised the use of amaranth peptides as a potential dietary supplement. Further studies are mandatory to assess if this inhibitory property also affects the secretion of other pro-inflammatory cytokines and chemokines. In vivo studies are being conducted in experimental models of mucosal inflammation to investigate the impact of these modulatory peptides in different inflammatory settings. Overall, we propose the use of Amaranth peptides in functional foods to complement therapies for IBD or other NF-kB-mediated inflammatory disorders. 


\section{Acknowledgements}

The authors acknowledge the financial support from Agencia Nacional de Promoción Científica y Tecnológica (ANPCyT, Argentina), Project PICT-2012 0937. The authors are members of the National Council Research (CONICET, Argentina).

\section{REFERENCES}

Adibi, S. A. (1997). The oligopeptide transporter (Pept-1) in human intestine: Biology and function. Gastroenterology, 113(1), 32-340.

Adler-Nissen, J. (1979). Determination of the degree of hydrolysis of food protein hydrolysates by trinitrobenzenesulfonic acid. Journal of Agricultural and Food Chemistry, 27(6), 1256-1262.

Bach, J. F. (2005). Infections and autoimmune diseases. Journal of Autoimmunity, 25(Suppl.), 74-80.

Bandyopadhaya, A., \& Chaudhuri, K. (2009). Differential modulation of NF-kappaB-mediated pro-inflammatory response in human intestinal epithelial cells by cheY homologues of Vibrio cholerae. Innate Immunity, 15(3), 131-142.

Barnes, P. J., \& Karin, M. (1997). Nuclear factor-kappaB: A pivotal transcription factor in chronic inflammatory diseases. The New England Journal of Medicine, 336(15), 1066-1071.

Barrio, D. A., \& Añón, M. C. (2010). Potential antitumoral properties of proteins isolated from Amaranth seeds. European Journal of Nutrition, 49, 73-82.

Bettenworth, D., Buyse, M., Böhm, M., Mennigen, R., Czorniak, I., Kannengiesser, K., Brzoska, T., Luger, T. A., Kucharzik, T., Domschke, W., Maaser, C., \& Lügering, A. (2011). The tripeptide $\mathrm{kdPT}$ protects from intestinal inflammation and maintains intestinal barrier function. American Journal of Pathology, 179(3), 1230-1242.

Borenfreund, E., Babich, H., \& Martin-Alguacil, N. (1988). Comparisons of two in vitro cytotoxicity assays - The neutral red (NR) and tetrazolium MTT tests. Toxicology in Vitro, 2(1), 1-6.

Brzoska, T., Luger, T. A., Maaser, C., Abels, C., \& Böhm, M. (2008). Alpha-melanocyte-stimulating hormone and related tripeptides: Biochemistry, antiinflammatory and protective effects in vitro and in vivo, and future perspectives for the treatment of immune-mediated inflammatory diseases. Endocrine Reviews, 29(5), 581-602.

Caselato-Sousa, V., \& Amaya-Farfán, J. (2012). State of knowledge on amaranth grain: A comprehensive review. Journal of Food Science, 77, R93-R104.

Chatterton, D. E. W., Ninh Nguyen, D., Brandt Bering, S., \& Torp Sangild, P. (2013). Anti-inflammatory mechanisms of bioactive milk proteins in the intestine of newborns. The International Journal of Biochemistry \& Cell Biology, 45, 1730-1747.

Council of the European Union. (2007). No. 1924/2006 of the European Parliament and of the Council of 20 December 2006 on nutrition and health claims made on foods. Official Journal of the European Union, pp. 3-18.

Dalmasso, G., Charrier-Hisamuddin, L., Thu Nguyen, H. T., Yan, Y., Sitaraman, S., \& Merlin, D. (2008). PepT1-mediated tripeptide KPV uptake reduces intestinal inflammation. Gastroenterology, 134(1), 166-178.

Desreumaux, P. (2004). Digestive tract immunology and Crohn disease. Archives de Pédiatrie: Organe Officiel De La Sociéte Française De Pédiatrie, 11(6), 539-541.

Dia, V. P., Wang, W., Oh, V. L., de Lumen, B. O., \& Gonzalez de Mejía, E. (2009). Isolation, purification and characterization of lunasin from defatted soybean flour and in vivo evaluation of its anti-inflammatory activity. Food Chemistry, 114, 108-115.

Feillet, H., \& Bach, J. F. (2004). Increased incidence of inflammatory bowel disease: The price of the decline of infectious burden? Current Opinion in Gastroenterology, 20(6), 560-564.

Fritz, M., Vecchi, B., Rinaldi, G., \& Añon, M. C. (2011). Amaranth seeds protein hydrolysates have in-vivo and in-vitro anti hypertensive activity. Food Chemistry, 126, 878-884.

Grammatikos, A. P. (2008). The genetic and environmental basis of atopic diseases. Annals of Medicine, 40(7), 482-495.

Guzmán-Maldonado, S. H., \& Paredes-López, O. (1998). Production of high-protein flours as milk substitutes. ACS Symposium Series, 708, 66-79.

Hasler, C. M. (2002). Functional foods: Benefits, concerns and challenges - A position paper from the American Council on Science and Health. Journal of Nutrition, 132(12), 3772-3781.

Hernandez-Ledesma, B., Hsieh, C. C., \& de Lumen, B. O. (2009). Antioxidant and anti-inflammatory properties of cancer preventive peptide lunasin in RAW 264.7 macrophages. Biochemical and Biophysical Research Communication, 390, 803808.

Huerta-Ocampo, J. A., \& Barba de la Rosa, A. P. (2011). Amaranth: A pseudo-cereal with nutraceutical properties. Current Nutrition \& Food Science, 7, 1-9.

Ito, T., Carson, W. F., 4th, Cavassani, K. A., Connett, J. M., \& Kunkel, S. L. (2011). CCR6 as a mediator of immunity in the lung and gut. Experimental Cell Research, 317(5), 613-619.

Kannengiesser, K., Maaser, C., Heidemann, J., Luegering, A., Ross, M., Brzoska, T., Bohm, M., Luger, T. A., Domschke, W., \& Kucharzik, T. (2008). Melanocortin-derived tripeptide KPV has anti-inflammatory potential in murine models of inflammatory bowel disease. Inflammatory Bowel Disease, 14(3), 324-331.

Kanu, P. J., Zhu, K., Baby Kanu, J., Zhou, H., Qian, H., \& Zhu, K. (2007). Biologically active components and nutraceuticals in sesame and related products: A review and prospect. Trends in Food Science \& Technology, 18(12), 599-608.

Kao, C. Y., Huang, F., Chen, Y., Thai, P., Wachi, S., Kim, C., Tam, L., \& Wu, R. (2005). Up-regulation of CC chemokine ligand expression in human airway epithelium by IL-17 through a JAK-independent but MEK/NF-kappaB-dependent signaling pathway. Journal of Immunology, 175(10), 6676-6685.

Klement, E., Lysy, J., Hoshen, M., Avitan, M., Goldin, E., \& Israeli, E. (2008). Childhood hygiene is associated with the risk for inflammatory bowel disease: A population-based study. The American Journal of Gastroenterology, 103(7), 1775-1782.

Korhonen, H., \& Pihlanto, A. (2006). Bioactive peptides: Production and functionality. International Dairy Journal, 16(9), 945-960.

Liang, R., Fei, Y. J., Prasad, P. D., Ramamoorthy, S., Han, H., YangFeng, T. L., Hediger, M. A., Ganapathy, V., \& Leibach, F. H. (1995). Human intestinal H+/peptide cotransporter. Cloning, functional expression, and chromosomal localization. The Journal of Biological Chemistry, 270(12), 6456-6463.

Lodes, M. J., Cong, Y., Elson, C. O., Mohamath, R., Landers, C. J., Targan, S. R., Fort, M., \& Hershberg, R. M. (2004). Bacterial flagellin is a dominant antigen in Crohn disease. Journal of Clinical Investigation, 113, 1296-1306.

Martinez, E. N., \& Añón, M. C. (1996). Composition and structural characterization of amaranth protein isolates. An electrophoretic and calorimetric study. Journal of Agricultural and Food Chemistry, 44, 2523-2530.

Merlin, D., Si-Tahar, M., Sitaraman, S. V., Eastburn, K., Williams, I., Liu, X., Hediger, M. A., \& Madara, J. L. (2001). Colonic epithelial $\mathrm{hPepT} 1$ expression occurs in inflammatory bowel disease: Transport of bacterial peptides influences expression of MHC class 1 molecules. Gastroenterology, 120(7), 1666-1679. 
Montoya-Rodriguez, A., Gonzalez de Mejia, E., Dia, V. P., ReyesMoreno, C., \& Milan-Carrillo, J. (2014). Extrusion improved the anti-inflammatory effect of amaranth (Amaranthus hypochondriacus) hydrolysates in LPS-induced human THP-1 macrophage-like and mouse 264.7 macrophages by preventing activation of NF-kB signaling. Molecular Nutrition \& Food Research, 58, 1028-1041.

Mosmann, T. (1983). Rapid colorimetric assay for cellular growth and survival: Application to proliferation and cytotoxicity assays. Journal of Immunological Methods, 65(1-2), 55-63.

Nempont, C., Cayet, D., Rumbo, M., Bompard, C., Villeret, V., \& Sirard, J. C. (2008). Deletion of flagellin's hypervariable region abrogates antibody-mediated neutralization and systemic activation of TLR5-dependent immunity. Journal of Immunology, 181, 2036-2043.

Nenci, A., Becker, C., Wullaert, A., Gareus, R., Van Loo, G., Danese, S., Huth, M., Nikolaev, A., Neufert, C., Madison, B., Gumucio, G., Neurath, M. F., \& Pasparakis, M. (2007). Epithelial NEMO links innate immunity to chronic intestinal inflammation. Nature, 446(7135), 557-561.

Orsini Delgado, M. C., Galeano, M., Añón, M. C., \& Tironi, V. A. (2015). Amaranth peptides form simulated gastrointestinal digestion: Antioxidant activity against reactive species. Plant Food for Human Nutrition, 70, 27-34.

Sabbione, A. C., Scilingo, A. A., \& Añón, M. C. (2015). Potential antithrombotic activity detected in Amaranth proteins and its hydrolysates. LWT - Food Science and Technology, 60, 171-177.

Savu, A., Potter, J., Li, S., \& Yasui, Y. (2008). Breast cancer and microbial cancer incidence in female populations around the world: A surprising hyperbolic association. International Journal of Cancer, 123(5), 1094-1099.
Schägger, H. (2006). Tricine-SDS-PAGE. Nature Protocols, 1(1), 16-22. Sloan, A. E. (1999). The new market: Foods for the not-so-healthy. Food Technology, 53(2), 54-60.

Smaldini, P. L., Stanford, J., Romanin, D. E., Fossati, C. A., \& Docena, G. H. (2013). Down-regulation of NF- $\mathrm{kB}$ signaling by Gordonia bronchialis prevents the activation of gut epithelial cells. Innate Immunity, 20(6), 626-638.

Soboll, G., Crane-Godreau, M. A., Lyimo, M. A., \& Wira, C. R. (2006). Effect of oestradiol on PAMP-mediated CCL20/MIP-3 alpha production by mouse uterine epithelial cells in culture. Immunology, 118(2), 185-194.

Tironi, V., \& Añón, M. C. (2010). Amaranth proteins as a source of antioxidant peptides. Effect of proteolysis. Food Research International, 43, 315-322.

Vecchi, B., \& Añón, M. C. (2009). ACE inhibitory tetrapeptides from Amaranthus Hypochondriacus 11S globulin. Phytochemistry, 70, 864-870.

Wang, W., \& Gonzalez de Mejia, E. (2005). A new frontier in soy bioactive peptides that may prevent age-related chronic diseases. Comprehensive Reviews in Food Science and Food Safety, $4(4), 63-78$.

Weinstock, J. V., \& Elliott, D. E. (2009). Helminths and the IBD hygiene hypothesis. Inflammatory Bowel Diseases, 15(1), 128133.

Yoon, S.-I., Kurnasov, O., Natarajan, V., Hong, M., Gudkov, A. V., Osterman, A. L., \& Wilson, I. A. (2012). Structural basis of TLR5-flagellin recognition and signaling. Science, 335(6070), 859-864.

Zhao, Y., Yang, J., Shi, J., Gong, Y.-N., Lu, Q., Xu, H., Liu, L., \& Shao, F. (2011). The NLRC4 inflammasome receptors for bacterial flagellin and type III secretion apparatus. Nature, 477(7366), 596-600. 